\title{
Analysis of corrosion damage in a boiler made of AISI 304L stainless steel
}

\begin{abstract}
The corrosion damage near the welded joint in the boiler of AISI 304L stainless steel was analysed. During welding, heat tint was formed near the weld on the inner surface of the boiler, because shielded gas was not applied. Due to the presence of heat tint and crevice in the welded joint, pitting corrosion occurred which caused the perforation and leakage of the boiler. Several procedures are proposed to prevent localised forms of corrosion (pitting and crevice corrosion) near the welded joint of the boiler.
\end{abstract}

Key words: stainless steels, welding, heat tint, corrosion

\section{INTRODUCTION}

During welding of stainless steels, temperatures above $300{ }^{\circ} \mathrm{C}$ are reached, and as a consequence, a thermal oxide, also known as a heat tint or weld discoloration, is formed on the surface adjacent to the weld. The thickness of the oxide layer next to the weld depends on the temperature, heating time, and oxygen concentration in the shielding gas. This heat tinted zone has a lower corrosion resistance compared to the parent metal and it is more susceptible to local corrosion attack [1-4].

Formation of a chromium rich layer, thicker than a passive layer and with a configuration more like scaling, leads to chromium depletion in the layer beneath the oxide (heat tint). Corrosion attack on the oxide surface and in the chromium depleted layer may initiate pitting or crevice corrosion at conditions where the stainless steel would normally be resistant [3, 4].

The most common types of corrosion in stainless steels and their welded joints are pitting, crevice corrosion, stress-corrosion cracking (SCC) and intergranular corrosion [5-8].

Pitting corrosion is highly localized corrosion attack in the form of corrosion holes (pits). The pits are formed on the places of destruction of protecttive film on stainless steels surface. If the film is damaged mechanically or chemically, it can be renewed or pitting corrosion process will occur. In the presence of halide ions, especially $\mathrm{Cl}^{-}$ions, pits formation usually takes place $[9,10]$. With increasing temperature tendency of stainless steels to pits formation increases. Formation of the stabile pits will not occur if the temperature is lower than some critical value, which is called the critical pitting temperature.

In the case of welded joints, pits are often formed due to a specific microstructure of the welded

\footnotetext{
Author's address: Institute GOŠA, Milana Rakića 35, Belgrade, Serbia

Received for Publication: 11. 08. 2013.

Accepted for Publication: 26. 10. 2013.
}

joints. Pits are easier to form in places of metallurgical heterogeneity. For example, chromium-depleted areas in the austenitic stainless steels heated to a temperature at which sensitization occurs, are susceptible to pitting. Pits can also be formed at interfaces austenite-ferrite in stainless steels welds. Probability of pit formation in the weld metal is high, due to the micro segregations in the dendrite structure. Additional materials with better resistance to pitting corrosion than a base metal are produced today $[5,6]$.

Crevice corrosion most often occurs in places of constructive elements contact, when they form a crevice (usually $0.1 \mathrm{~mm}$ ). This type of corrosion is caused by differential aeration. In areas with higher concentration of oxygen, cathodic reaction takes place, while in places with lower concentration, anodic reaction occurs. Thus, due to the difficult access of oxygen, the metal within the crevice rapidly dissolves. Also, because of hydrolysis of metal ions in the crevice, the acidic environment is formed, which further accelerates metal dissolution. This type of corrosion undergoes to similar laws as pitting corrosion. If the conductivity of electrolyte is high and the cathodic surface of metal outside the crevice is large, the rate of metal dissolution in the crevice is greater [11].

Physical and mechanical defects in the welding joints, such as micro cracks, hot and cold cracks, gaps of incomplete penetration, are places where the electrolyte remains. On these places crevice corrosion can take place, particularly in environments containing chloride ions. Stainless steels with higher chromium, and especially molybdenum content, are much more resistant to this type of corrosion $[5,6]$.

Stress corrosion cracking (SCC) is a process which occurs when the necessary electrochemical, mechanical and metallurgical conditions exist. SCC usually takes place by influence of specific ions that are present in corrosion environment. Chloride ions cause cracking of aluminium alloys and stainless steels. SCC usually starts at the surface 
defects, formed during mechanical processing, welding, etc. Also, it can start at the surface defects created during the process of corrosion, such as pitting, intergranular corrosion, etc. [12, 13].

Welded joints may be susceptible to SCC in a specific corrosion environment, because they are often exposed to residual or externally imposed stress, of relatively high level. Residual stresses are most important factor for initiation and propagation of stress-corrosion crack. Welding parameters affect the magnitude and distribution of internal residual stresses, which are proportional to the heat input and the size of the weld. The post weld heat treatment can reduce the formation of stress-corrosion cracks during exploitation, because of redistribution and reduction of internal tensile stress in the welded joints. Welded joints are favourable places for the stress-corrosion cracks formation, because of heterogeneous microstructure. Senzibilised $18 \mathrm{Cr}-8 \mathrm{Ni}$ austenitic stainless steels are prone to intergranular stress corrosion cracking [14].

Intergranular corrosion most commonly occurs in austenitic stainless steels. At high temperatures $\left(\mathrm{T}>1030^{\circ} \mathrm{C}\right)$ chromium carbides are completely dissolved. However, due to the slow cooling or annealing in the temperature range of 420 to 820 ${ }^{\circ} \mathrm{C}$, chromium carbides are precipitated on the grain boundaries. The rate of diffusion of chromium in austenite is low at these temperatures. As a result, grain boundary areas become impoverished in chromium. If the chromium content is reduced below $12 \%$, which is necessary for the maintenance of the protective passive film, grain boundary areas become sensitized and prone to intergranular corrosion. In the corrosive environment, this area dissolves faster than other grain regions $[5,6]$.

\section{RESULTS}

Nominal and actual chemical composition of the base metal and the filler metal are given in table 1. Table 1 - Chemical composition of the base metal (AISI 304L) and filler metal (AISI 308).

\begin{tabular}{|l|c|c|c|c|c|c|c|c|}
\hline \multicolumn{1}{|c|}{ Stainless steel } & $\mathrm{C}$ & $\mathrm{Cr}$ & $\mathrm{Ni}$ & $\mathrm{Mn}$ & $\mathrm{P}$ & $\mathrm{S}$ & $\mathrm{Si}$ & $\mathrm{Fe}$ \\
\hline AISI 304L & 0.03 & $18.0-20.0$ & $8.0-12.0$ & 2.00 & 0.045 & 0.030 & 0.75 & rest \\
\hline AISI 304L & - & 18.96 & 7.85 & 1.59 & - & 0.00 & 0.49 & rest \\
\hline AWS ER308LSi & $<0.025$ & $19.0-21.0$ & $10.0-12.0$ & 2.00 & $<0.025$ & $<0.015$ & 0.90 & rest \\
\hline AWS ER308LSi ${ }^{*}$ & - & 19.08 & 9.91 & 1.77 & - & 0.00 & 0.51 & rest \\
\hline
\end{tabular}

${ }^{*}$ Actual chemical composition was determined by SEM/EDS method.

The outer side of the boiler with longitudinal and circumferential weld is shown in Fig. 1a. The welding was performed in the shielding gas (formier gas). The position of the boiler perforation is presented in Fig. 1b. The leakage of the water in this place was significant.

The appearance of the inner side of the boiler with the circumferential welded joint is shown in
The aim of this work is examination of heat tint influence, formed during welding of the boiler of stainless steel AISI 304L, on the appearance of localised forms of corrosion, such as pitting and crevice corrosion. The water in boiler contains relatively low concentration of chlorides and other corrosive agents. During exploitation the localised corrosion caused the perforation of the boiler and the water leakage.

\section{MATERIAL AND TEST METHODS}

\section{Material and welding procedure}

Boiler was made of stainless steel AISI 304L. Boiler welding was performed by MIG procedures (filler metal AWS ER308LSi). Longitudinal weld was performed applying shielding gas on both (root and face) side of the weld, while circumferential weld was performed applying shielding gas only on the face side.

\section{Test methods}

The appearance of corrosion damages on the boiler was shown using the appropriate photographs of the characteristic places.

\section{Metallographic examinations}

The metallographic test was carried out on the cross section of the pipe samples. The test was performed by using Carl Zeiss microscope with Neophot 30 camera.

\section{Scanning electron microscopy (SEM)}

SEM/EDS analysis was performed using the scanning electron microscope J EOL J SM-6610LV coupled with INCA350 energy-dispersive analytic unit. The qualitative Electron Probe Micro Analysis (EPMA) was applied. 


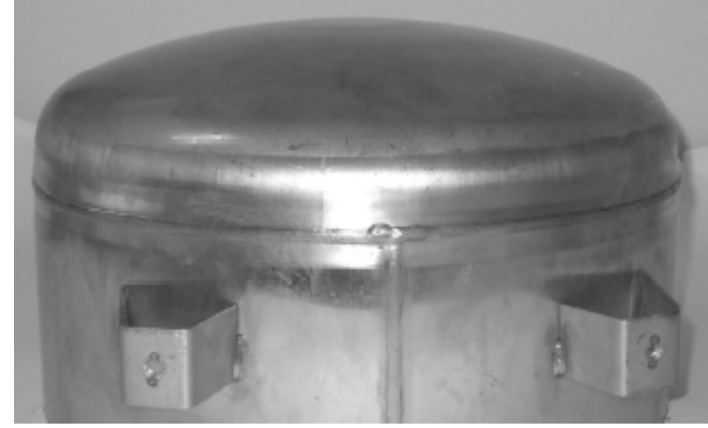

a)

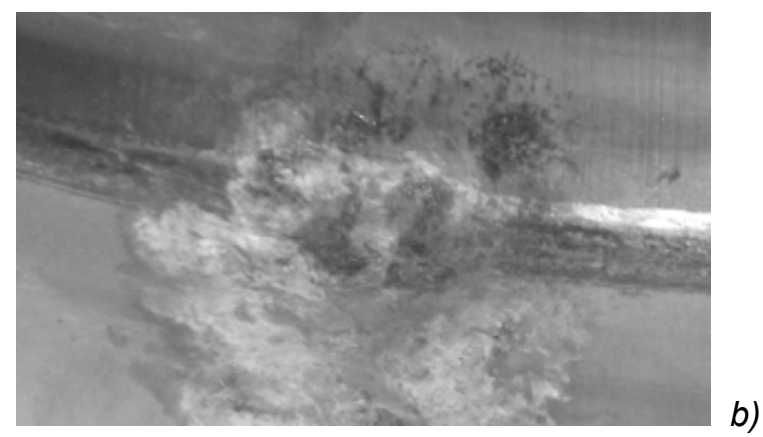

Figure 1 - General appearance of the outer side of the boiler: a) welded joints, b) corrosion damage near the welded joint
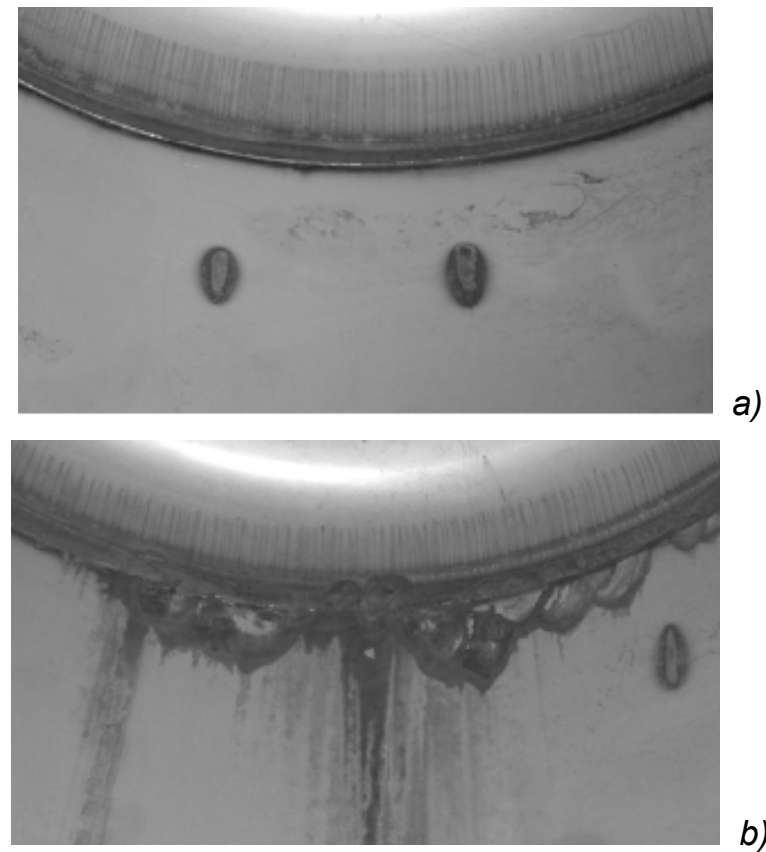

Figure 2 - General appearance of the inner surface of the boiler, a) heat tinted zones, b) corrosion damages near the welded joint

Microstructural examination of the base metal has revealed that the microstructure is austenitic, with twins of austenite (Fig. $4 a$ and b). The microstructure is regular, without imperfections (inclusions and impurities). Grain size index was shown to be 6, according to ISO 643: 2003, at magnification $\times 100$.
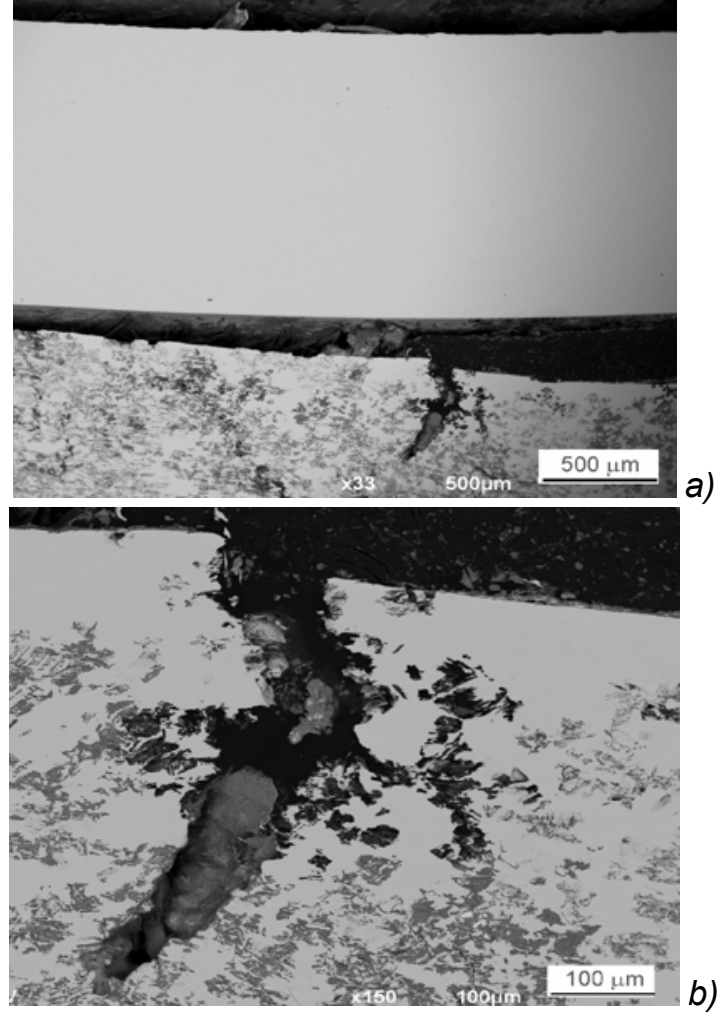

Figure 3 - SEM microphotographs of the corroded surface with a) crevice and b) pitting
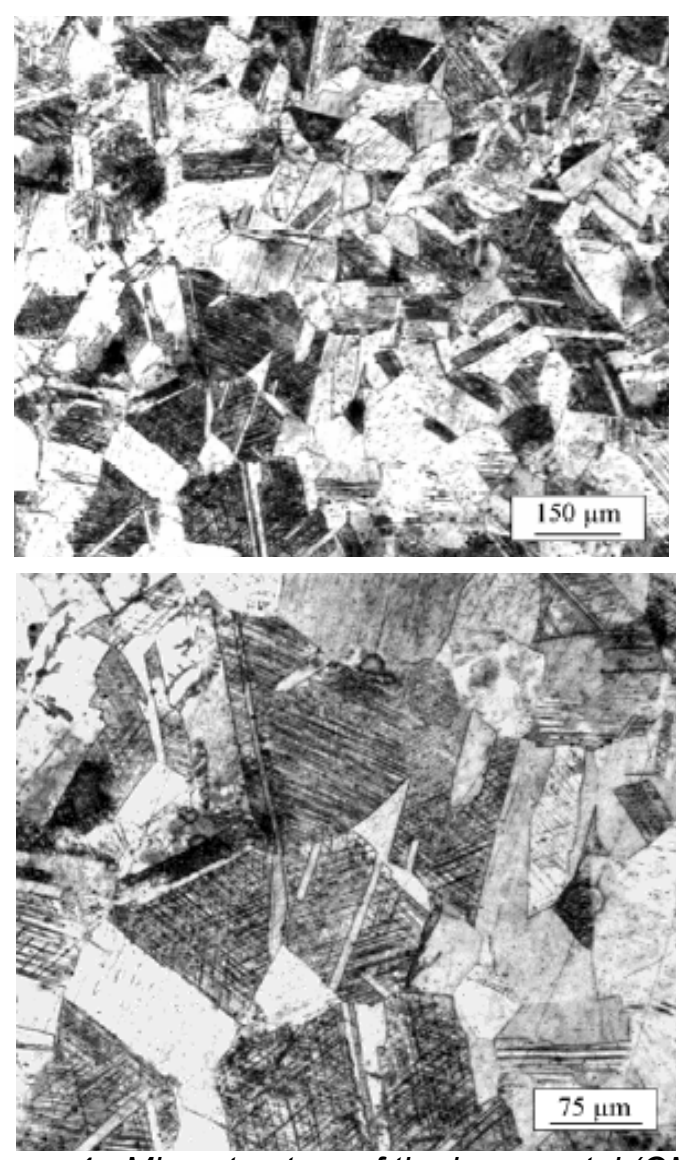

Figure 4 - Microstructure of the base metal (OM). Etched in aqua regia. 


\section{DISCUSSION}

The thickness of the heat tint cannot be measured directly. However, the thickness and the corrosion resistance of the heat tint layer can be approximately determined according to the heat tint colour. Tinting at the root side of a weld is a criterion for the assessment of the weld acceptability. A yellow tint is admissible at the root side, but at the weld face a blue tint is admissible too. Up to a thickness of $20 \mathrm{~nm}$ the oxide (heat tint) shows a metallic shine. An increased thickness results in changes of heat tint colours ranging from yellow, brown, blue to black ones.

Heat tint levels from hardly visible to significant scale formations are illustrated by colour photos and ranged from $A$ to $G$ (Fig. 5). Requirement specified as acceptable heat tint level is usually level B-C. A heat tint of straw yellow (level C) usually indicates the limit between unaffected properties of austenitic stainless steels and a more or less pronounced loss of resistance toward pitting and crevice corrosion.

Stainless steel AISI 304L is not prone to pitting and crevice corrosion if the chloride content in water and water temperature do not exceed the critical levels (Fig. 6).

Heat tint in the root of circumferential welded joint on the inner side of boiler was formed because the welding was performed without the shielding gas. Heat tint on the outer side of boiler was not formed because the shielding gas was used during welding. The longitudinal welded joint was also formed in the shielding gas (root and the face side of the weld) and the heat tint was not formed.

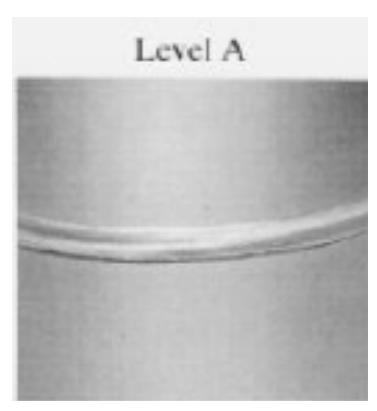

Level C

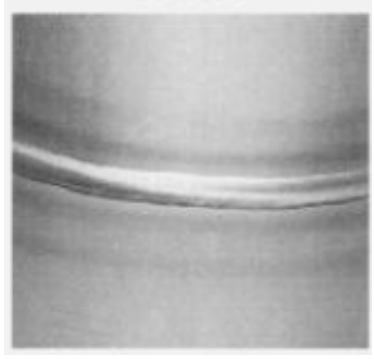

Level E
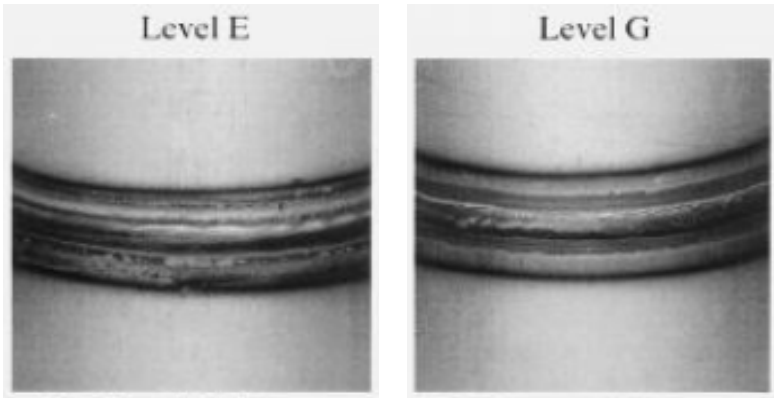

Figure 5 - Reference Colour Chart for different level of the heat tint [15]

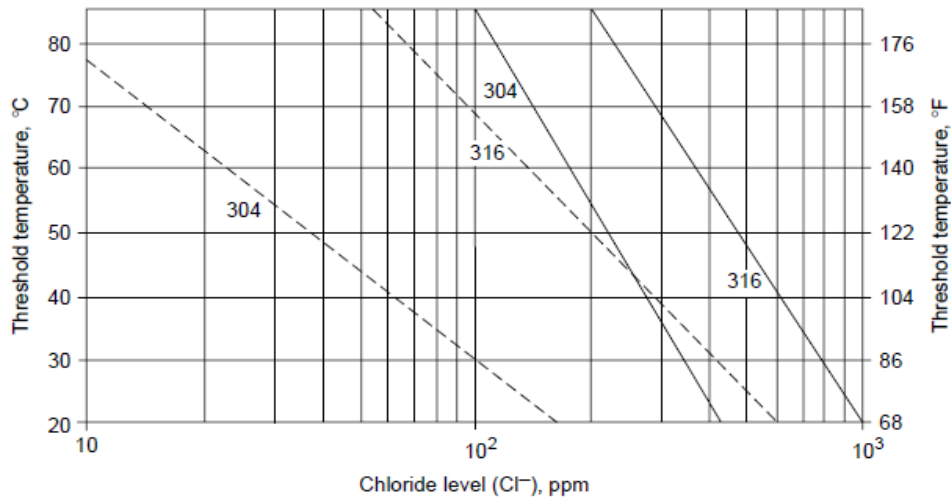

Figure 6 - Risk of pitting (solid line) and crevice corrosion (dashed line) of standard grades of stainless steels in waters with varying chloride levels [16]

Corrosion processes occurred in the circumferential welded joint and oval heat tinted surfaces near the circumferential welded joint, because of heat tint formation in the inner side of the boiler. On the oval heat tinted surfaces general corrosion occurred with uniform thinning of the metal. The appearance of the local forms of corrosion was not noticed.
During designing of the boiler the crevice was formed in the region of the circumferential welded joint (Figs. 2 and 3 ). In the presence of the crevice and the heat tint in this region the stainless steel AISI 304L corroded during exploitation. The formation and propagation of pits inside the crevice resulted in perforation of the boiler wall near the circumferential welded joint. 


\section{CONCLUSIONS}

The corrosion damage in the boiler of AISI 304L stainless steel was analysed. It was shown that heat tint was formed near the circumferential weld joint on the inner side of the boiler. Corrosion resistance of the heat tinted zone is lower compared to the base metal. Due to the presence of heat tint and crevice in the welded joint, pitting corrosion occurred which caused the perforation and leakage of the boiler.

The following procedures can be proposed to prevent local forms of corrosion in the boiler of the stainless steel AISI 304L:

Designing of the boiler without crevices.

Welding should be performed in the shielding gas to prevent formation of the heat tinted zones.

If formed, heat tint should be removed according to the standard ASTM A380.

Replacement of the stainless steel AISI 304L with the stainless steel AISI 316/316L which contains 2-3\% Mo, because this stainless steel is far more resistant to pitting and crevice corrosion.

\section{Acknowledgements}

This work was co-financed from the Ministry of education, science and technological development of the Republic of Serbia through projects TR 34028 and TR 34016.

\section{REFERENCES}

[1] J.R. Davis, Corrosion of Austenitic Stainless Steel Weldments, in Corrosion of Weldments, ASM International, (2006), 43-75.

[2] I. Juraga, V. Šimunović, Đ. Španiček, (2007), Contribution to the study of effects of surface state of welded joints in stainless steel upon resistance towards pitting corrosion, Metalurgija, Vol. 46, No. 3 , 185-189.

[3] J. Łabanowski and M. Głowacka, (2011), Heat tint colours on stainless steel and welded joints, Welding International, Vol. 25, No. 7, 509-512.

[4] B.M. Bobić, B.V. Jegdić, M.M., (2013), Prokolab, Influence of heat tint on corrosion resistance of stainless steels, Zavarivanje i zavarene konstrukcije, Vol. 58, No. 3, 121-126.
[5] B. Bobić i B. Jegdić, (2005), Korozija zavarenih spojeva, Deo III: Nerđajući čelici, Zavarivanje i zavarene konstrukcije, Vol. 50, No. 4, 217-223.

[6] B. Bobić i B. Jegdić, (2005), Korozija zavarenih spojeva, Deo I: Vidovi korozije zavarenih spojeva, Zavarivanje i zavarene konstrukcije, Vol. 50, No. 1, 33-39

[7] B. Pejović, V. Mićić, M. Tomić, (2012), Investigation influence of characteristics parameters of surface quality on some stainless steel at electrochemical scraping processing, Zaštita materijala, Vol. 53, No. 4, 305-312.

[8] A. Češnovar, M. Salova, (2013), Appearance, management and prevention of corrosion in the brewing industry, Zaštita materijala, Vol. 54, No. 2, 135-140.

[9] G.S. Frankel, (1998), Pitting corrosion of metals, a review of the critical factors, J. Electrochemic. Soc., Vol. 145, No. 6, 2186-2198.

[10] [M.G. Alvarez, J. R. Galvele, Pitting Corrosion, Shreir's Corrosion, Volume Two: Corrosion in Liquids, Corrosion Evaluation, Academic Press, Oxford, (2010), 772-800.

[11] R.G. Kelly, Crevice Corrosion, Corrosion: Fundamentals, Testing, and Protection, Vol 13A, ASM Handbook, ASM International, (2003), 242-247.

[12] R.H. Jones, Stress-Corrosion Cracking, in Corrosion: Fundamentals, Testing, and Protection, Vol. 13A, ASM Handbook, ASM International, (2003), 346-366

[13] V. Kain, Stress corrosion cracking (SCC) in stainless steels, in Stress corrosion cracking, Theory and practice, Edited by: Raja, V. S. and Shoji, T., Oxford, Cambridge, Philadelphia, New Delhi, (2011), 199244.

[14] B.V. Jegdić, B.M. Bobić, A.B. Alil, (2012), Naponska korozija metala i legura i njihovih zavarenih spojeva, deo I: uslovi nastanka naponske korozije, Zavarivanje i zavarene konstrukcije, Vol. 57, 35-41.

[15] J.V. Hansen, Corrosion failures in stainless steel pipe systems, The FORCE Institute, Denmark, 1977.

[16] J.F. Grubb, T. De Bold, J.D. Fritz, Corrosion of Wrought Stainless Steels, Corrosion: Materials, ASM Handbook, Vol. 13B, ASM International, (2005), 5477.

\section{IZVOD}

ANALIZA KOROZIONIH OŠTEĆENJA NA BOJLERU OD NERĐAJUĆEG ČELIKA AISI 304L

Analizirana je pojava korozionih oštećenja u blizini zavarenog spoja na bojleru od nerđajućeg čelika AISI 304L. U toku zavarivanja došlo je do obrazovanja termičkog oksida (heat tint) u blizini zavarenog spoja na unutrašnjoj strani bojlera, zbog odsustva zaštitnog gasa tokom zavarivanja. Usled postojanja zazora u zavarenom spoju i prisustva heat tint-a došlo je do pojave tačkaste korozije, što je prouzrokovalo proboj zida bojlera i curenje. Predloženo je nekoliko postupaka za sprečavanje pojave lokalizovanih vidova korozije (tačkasta i korozija u zazorima) u blizini zavarenog spoja na bojleru.

Ključne reči: nerđajući čelici, zavarivanje, termički oksid (heat tint), korozija

Originalni naučni rad

Primljeno za publikovanje: 11. 08. 2013.

Prihvaćeno za publikovanje: 26. 10. 2013. 
JOVAN JOVANOVIĆ, Name of institution, city, state; Faculty of Electrical Engineering, Belgrade, Serbia

JOHN SMITH, University of .... font Arial, font size 11, italic

\title{
Instructions for Authors - the title of the work (up to two lines) Style: font Arial, font size 14, bold
}

\begin{abstract}
- no longer than 150 words (lines 10-12), should contain subject matter and objective of the work, a brief overview of the methods and the main results so that its original text can be used in reference periodicals, font Arial, font size 11.

Key words: (up to six terms), which provide turn an article in Information systems.
\end{abstract}

\section{INTRODUCTION}

The paper should be written in Serbian or English language. The paper should include: statement, introduction, experimental part, results and discussion, conclusion, references and taught in English language if the paper is written in the Serbian language and vice versa. The paper should be written single-spaced (A4 format). In the pages margins should be: top $3 \mathrm{~cm}$, the left and right $2.20 \mathrm{~cm}$, using font Arial, font size 11. All papers will be reviewed.

\section{TITLE ( eg , EXPERIMENTAL WORK)}

Subtitles are typed in capital letters (bold), font size 11.

Tables and figures are inserted at the place where we talk about them. In the text refer to the serial number of tables / images.

Above the table there should be naziv. Below the image states her name, for example:

Table 1 -. Results of experimental measurements., italic

Figure 1 - Results of the simulation, italic

\section{SUBTITLE (e.g., RESULTS)}

Numbering of the equations do the right margin in small (round) brackets, eg.:

$$
J \frac{d \omega(t)}{d t}+F \omega(t)=T_{e}(t)-T_{o}(t) \text {. }
$$

Units: Use the International System of Units $(\mathrm{SI})$ and the Law on the units of measurement and measures, as well as the recommended IUPAC symbols of chemical and physical size.

\section{TITLE (eg CONCLUSION)}

The manuscript, prepared as a MS Word doc files, e-mailed as an attachment to the address of the editor, Prof.. Časlav Lačnjevca: e-mail: ukilaki@eunet.rs

Acknowledgements (Acknowlegements): Specifies the name and number of the project from which flowed the results and the name of the institution which funded the research presented in the paper.

\section{REFERENCES}

References within the text says [square] brackets by numerals, so that the same source cites only one, for example,

[1], [2,3], [4-8]. The abbreviated name of the journal should be cited according to the International Code for the shortening of periodicals ((http://www.efm.leeds.ac.uk/ mark/lSlabbr/ ) .

[1] JOURNAL: Sheng J.W. He M. Shi, H.C.(2007) A highly specific immunoassay for microcystin-LR detection based on a monoclonal antibody, Anal Chim Acta, 603,1,111-118.

[2] BOOKS: Gulišija Z., Lačnjevac Č.:Corrosion and Protection Material, ITNMS, (2012) Belgrade.

[3] CHAPTER in the BOOK: M. Stojanovic, Lačnjevac C., Lopičić Z. (2012) Corrosion and Corrosion Behavior of depleted uranium, In: Gulišija Z.. Lačnjevac C. (Ed), Corrosion and Protection of Materials, ITNMS, Belgrade, pp 223261

[4] Text from the Web site: Maja Arslanagić M., Kandic - Maglajlić S. (2011) Manual for the source of scientific papers (http://www.efsa.unsa.ba/ef/docs/handbooks/manual economic web.pdf, 01.12.2013.)

\section{ABSTRACT}

At the end of the paper should be given the name of work and extract the key words in the English language, in the form of a Serbian language. 